\title{
ДИСТАНЦИОННЫЙ ЭКСПЕРИМЕНТ В КОГНИТИВНОЙ ЛИНГВИСТИКЕ
}

\author{
Алексеева Виктория Николаевна, \\ К.фрилол.н., дочент, Ярославский Государственный \\ университет им. П.Г. Демидова, г. Ярославль \\ aka_vscorpio@mail.ru
}

\section{DISTANCE EXPERIMENT IN COGNITIVE LINGUISTICS}

\section{Alekseeva}

Summary: The article describes the structure of a distance experiment in cognitive linguistics, conditions for remote users interaction and the sequence of distance experiment running. The method of remote experiment combines the principles of associative experiment and free definitions (to give a free description of sovietisms or ideologemes), as well as the method of deep introspection of the researcher, which restores all the chains of reactions to sovietisms or ideologemes in the responses of testees. The platforms for conducting the experiment were Z00M, Skype, and Facebook (video conferences and chats). The purity of the experiment was ensured by the fact that 15 representatives of the UK and 6 representatives of the US took part in the study, the age of the respondents was 18-77 years. The study showed that in most cases, foreigners in one way or another have difficulties in interpreting a particular unit of the Soviet period. It is explained by the fact that they rely on a personal system of meanings. However, in order to facilitate the understanding of these units, it is necessary to rely on the language values. They can be passed by using calculated variants, borrowings, definitions, analogs, and generic substitutions.

Keywords: distance experiment, associations, sovietisms, ideologemes, stimulus words. $\ni$ ксперимент подразумевает «исследование явлений и процессов путём их воспроизведения, моделирования в искусственных или естественных условиях» [1].

Дистанционный эксперимент предполагает собой непосредственное удаленное участие пользователя в выполнении эксперимента и возможность наблюдения за его результатами.

Эксперименты применяются в лингвистике, которая непосредственно связана с проблемами коммуникации. И.А. Стернин приводит следующие примеры лингвистических экспериментальных методов:

1. Свободный ассоциативный эксперимент;

2. Направленный ассоциативный эксперимент;

3. Метод субъективной дефиниции;

4. Экспликативный эксперимент;

5. Методика описания чувственного образа, вызываемого словом;

6. Метод письменной рефлексии (минисочинений)
Аннотация: В статье описана структура проведения дистанционного эксперимента в когнитивной лингвистике, условия для взаимодействия с удаленными пользователями и последовательность выполнения дистанционного эксперимента. Методика дистанционного эксперимента совместила в себе принципы ассоциативного эксперимента и свободных дефиниций (в свободной форме дать описание советизма или идеологемы), а также метод глубокой интроспекции исследователя, восстанавливающего все цепочки реакций на советизм или идеологему в ответах испытуемых. Площадками для проведения эксперимента стали платформы Z00M, Skype, Facebook (видео конференции и чаты). Чистоту эксперимента обеспечил тот факт, что в исследовании приняли участие 15 представителей Великобритании и 6 представителей США, возраст опрашиваемых составил 18 - 77 лет. Исследование показало, что в большинстве случаев иностранцы так или иначе испытывают затруднения при трактовке той или иной единицы советского периода. Это объясняется тем, что они опираются на личностную систему смыслов. Однако для того, чтобы облегчить понимание этих единиц, необходимо опираться на языковые значения. Их можно передать с помощью калькированных вариантов, заимствования, определения, аналога, родовидовой замены.

Ключевые слова: дистанционный эксперимент, ассоциации, советизмы, идеологемы, слова-стимулы.

по концепту;

7. Завершение экспериментальной фразы и т.д. [2, С. 25].

В данном исследовании использован свободный ассоциативный эксперимент, во время которого испытуемому предъявлялось слово-стимул и требовалось дать первые пришедшие на ум ассоциации [3]. В исследовании приняли участие 15 представителей Великобритании и 6 представителей США. Возраст опрашиваемых от 18 до 77 лет, что в известной мере обеспечило чистоту эксперимента.

Методика эксперимента совмещает в себе принципы ассоциативного эксперимента и свободных дефиниций (в свободной форме дать описание советизма или идеологемы), а также метод глубокой интроспекции исследователя, восстанавливающего все цепочки реакций на советизм или идеологему в ответах испытуемых.

Технология эксперимента: испытуемым предъявля- 
ется несколько слов-стимулов, на которые они должны отреагировать с помощью определённого ряда ассоциаций.

Площадки для проведения эксперимента: платформы ZOOM, Skype, Facebook (видео конференции и чаты).

Материал: 20 советизмов и советских идеологем, переданных на английский язык англоязычными переводчиками.

Инструкции: каждому опрашиваемому необходимо было указать свой возраст, страну проживания, в двухтрёх предложениях указать факты, известные им о России, а также о положении дел в СССР в 1920-1930х гг.

Каждому респонденту предлагались следующие вопросы:

\author{
“Master and Margarita" by M.A. Bulgakov \\ Questionnaire \\ 1. How old are you? \\ 2. What country and city do you live in? \\ 3. What do you know about Russia? (2-3 sentences) \\ 4. What do you know about USSR of 1920-1930ss? (2-3 \\ sentences) \\ 5. Have you read "Master and Margarita" by M.A. \\ Bulgakov? \\ 6. What do you associate these soviet units with?
}

Free ticket hound; Proletarian; Kulak; Saboteur; Intelligentsia; White guard; Komsomol girl; Interventionists; Solovki; Kislovodsk; Radio station; Sobering-up cell; Drunk tank; Pyramidon; Pork-pie hat; A state bond; The tenants' association; Kerosene burner; Primus stove; Communal kitchen.

В результате проведённого эксперимента оказалось возможным прийти к следующим выводам:

- При ответе на вопрос о том, какими сведениями о России они располагают, большинство (81 \%) ограничилось лишь поверхностными формулировками, которые можно практически выразить одной фразой «Russia is a great power with rich resources. Its president is Putin». 19 \% затруднились ответить на этот вопрос. Это доказывает, что иностранцы мало знают о ситуации, сложившейся в нашей стране, и основываются в своих суждениях и оценках на рядт стереотипных образов.

- Что же касается интересующего нас периода 1920-1930x гг., то здесь также наблюдается похожая ситуация. 95 \% дали общие ответы, смысл которых также можно сформулировать следующим образом «The USSR was controlled by Stalin, the most ruthless dictator. It was the hardest period for the country». 5 \% не смогли справиться с вопро-
COM.

- Больше половины респондентов (62 \%) читали «Мастера и Маргариту», что в принципе является довольно приятной неожиданностью, так как даже не все носители русского языка могут этим похвастаться. 38 \% либо читали некоторые главы романа, либо что-то о нём слышали.

Вопрос, связанный с ассоциациями на те или иные советизмы и идеологемы, оказался самым интересным, так как он позволил выявить, хорошо ли иностранцы знакомы с нашей культурой или их знания ограничиваются ассоциативным рядом «водка, бабушка, валенки, белые медведи», а также насколько результативными являются средства номинации внешнекультурных единиц. Оказалось, что трудности при понимании возникают во многих случаях. На основании ответов, полный список которых представлен в приложении, был составлен свой топ-лист самых замысловатых для иностранца советских единиц, начиная с самой сложной и заканчивая самой простой.

1. Free ticket hound (контрамарочник). Лишь 2 человека из 21 смогли правильно сформулировать значение данного советизма. Само слово «контрамарка» произошло от двух французских слов: «contre» - добавочный и «marque» - значок. По своей сути контрамарка является пропуском, который вместо билета выдаёт администратор театра некоторым лицам. Обладатели контрамарки (контрамарочники), таким образом, получают право бесплатного посещения представления.

В основном респонденты затруднились ответить на вопрос, связанный со значением данной единицы, либо трактовали её, исходя из первого значения слова hound (охотничья собака, борзая), опустив при этом 2 важные составляющие советизма free ticket. Интересно, с чем же связана трудность восприятия данной единицы. Понятие контрамарка не чуждо англоязычной культуре. Его английское соответствие - free pass. Что же касается слова контрамарочник, то адекватный вариант для его передачи - это соответствие paper. В электронном словаре Мультитран предлагается следующий пример использования paper в интересующем нас значении: «мы не знаем, сколько вчера было контрамарочников, но театр был полон»: перевод «how much paper there was yesterday we do not know but the hall was full». Поэтому, в данном случае некачественный перевод привёл к неправильной интерпретации идиокультуронима.

2. Sobering-up cell / Drunk tank (вытрезвитель) был объединён в одну группу на основании их синонимичности. Известный в советское время советизм вытрезвитель, понятен для носителей русского языка, но чужд для иностранцев, что подтверждается данными нашего исследования: drunk tank правильно интерпретировали 5 \% от общего числа опрошенных, sobering-up cell- 38 \% от общего 
числа.

3. White Guard (белогвардеец). Примечательно, что в данном случае $62 \%$ респондентов ограничились общим ответом, а именно army, Russian army. Хотя переводчики и воспользовались прямым соответствием данной единицы, из проведённого опроса понятно, что иноязычным читателям она не совсем знакома. Кем же являлись белогвардейцы? Белое антибольшевистское движение, сформировавшееся в ходе Гражданской войны 1917-1923 гг., боролось за свержение советской власти. Её представители выступали за единую и неделимую Россию. Поэтому ответ «русская армия» не отражает истинную суть рассматриваемого советизма. Некоторые иностранцы, столкнувшись с данной единицей, вспоминали первый роман Булгакова «Белая гвардия», но, это, к сожалению, единицы. Поэтому «спасательным кругом», конечно, является переводческий комментарий, который мог бы пояснить особенность данной единицы.

4. Pork-pie hat (шляпа пирожком). Ещё один советизм, в значении которого для носителей языка нет ничего необычного, чего не скажешь об иностранных читателях. Они в большинстве своём плохо осведомлены о значимости данной единицы в советской культуре. Предложенный вариант (дословно «свиной пирожок») привёл к следующим результатам: 67 \% испытуемых привели следующий ассоциативный ряд: a specific hat, a hat of an unusual form, что формально не противоречит действительности (хотя её форму едва ли можно назвать причудливой: поля средней длины, круглая тулья, вдавленный верх). Однако та самая «специфичность и необычность» не была подчёркнута. Шляпа пирожком не была просто одной из множества разновидностей шляп. Она была главным атрибутом советской интеллигенции. Дело в том, что после революции в Советском Союзе практически никто, кроме интеллигентов, не носил шляп. Вновь их стали носить как раз в 30х годах, в основном представители новой элиты, к которой Берлиоз себя явно относил. Эти сведения также требуется отразить в комментарии.

5. Solovki (Соловки). Название для Соловецких островов расположенных в Белом море, в романе - разговорный вариант названия Соловецкого лагеря особого назначения (СЛОН). На территории бывшего монастыря располагался Соловецкий концентрационный лагерь, один из самых ранних и наиболее известных советских лагерей. Последние заключенные были погружены на баржу и утоплены в Белом море в 1959 году. В романе Булгаков упоминает данный советизм в споре Берлиоза и Бездомного. Однако среди иностранцев этот советизм не так хорошо известен. 29 \% опрошенных ответили, что не имеют ни малейшего представления о том, что это.
6. Kislovodsk (Кисловодск). Свое название город получил благодаря изобилию источников знаменитой по всему миру лечебной углекислой воды «Нарзан». Кисловодск был излюбленным местом отдыха советских людей, однако стоит сделать оговорку: далеко не все советские люди могли себе позволить отдых в таком городе-курорте. Вот и в романе, эпизод в первой главе, когда Берлиоз думает о том, чтобы всё бросить и уехать в Кисловодск, даёт понять, что Берлиоз является человеком, по крайней мере, не нуждающимся в деньгах. Однако это понятно только для носителя русской культуры. Из нашего опроса следует, что 29 \% не знают, в какой связи упоминается этот город в романе. Остальные опрошенные просто отметили, что это один из русских городов, о чём нетрудно было догадаться и без романа.

7. Radio station (радиотеатр). Одна из самых трудных единиц для иностранцев. Разберёмся в его значении. В СССР радиотрансляции театральных постановок, прежде всего оперных спектаклей Большого театра, начались ещё в 20x годах, и датой рождения радиотеатра считается 25 декабря 1925 года, когда в студии Московского радио состоялась премьера первой советской радио пьесы - «Вечер у Марии Волконской»; хотя тот радиотеатр, который любили в СССР в 40-70x годах, сформировался позже. В СССР радиотеатр использовался и для пропаганды. Данные опроса показали, что 29 \% не знают, что же это такое. А $71 \%$ респондентов ограничились общим ответом, который можно выразить таким образом: a source of information, что не отражает всей специфики этой единицы.

8. Primus stove (примус).

Данные нашего исследования показывают, что 29 \% иностранцев не понимают значения этого советизма, а остальные опять-таки ограничились довольно общим ответом: popular in the USSR, stove, used for cooking.

9. Pyramidon (пирамидон). Пирамидон упоминается в английских словарях, как и «амидопирин». Но это средство, очевидно, мало знакомо англоязычному читателю, а аспирин знают все. $24 \%$ респондентов ответили, что не знакомы с данной единицей.

10. Kerosene burner (керосинка) - бытовой нагревательный прибор для приготовления и разогревания пищи на открытом огне, работающий на керосине, по принципу действия аналогичен керосиновой лампе, чрезвычайно популярный в СССР. Редкая коммунальная кухня обходилась без керосинки. Иностранцы плохо осведомлены о данном советизме: 19 \% затруднились ответить на вопрос, с чем же они ассоциируют данную единицу, остальные опять-таки ограничились односложными ответами, не отражающими специфику 
этой важной советской единицы.

11. A state bond (облигация). В целях финансирования отдельных мероприятий Советское правительство организовывало лотереи. Одним из видов таких лотерей был выпуск облигаций государственного займа, исполняющих роль ценных бумаг. Граждан «настойчиво просили» покупать государственные облигации на работе, так Мастер приобрел облигации в музее. Часто эти лотереи предусматривали розыгрыш значительной суммы денег. Так как в жилищах граждан было не много надежных мест, Мастер держал свою облигацию в корзине с грязным бельем.

Прямое соответствие в полной мере отражает исходный советизм. Хотя 19 \% опрошенных затруднились привести какие-либо ассоциации.

12. Kulak (кулачок). Один из наиболее ярких советизмов, упоминавшийся нами выше. Он также нуждается в комментарии, так как согласно проведённому нами опросу $19 \%$ вообще впервые столкнулись с рассматриваемой единицей.

13.Saboteur (вредитель). Прямое соответствие не противоречит данной идеологеме, тем не менее, опрос показал, что $19 \%$ не знают, что такое вредительство, а при более детальных расспросах иностранцев, стало ясно, что об истинном значении вредительства в СССР имеют представление лишь единицы, изучавшие этот вопрос более подробно.

14. Interventionists (интервенты). В ранний советский период постоянно говорили о врагах революции и иностранных интервентах, пытающихся свергнуть молодое государство рабочих и крестьян. Данные единицы выражали неприятие, во-первых, всего иностранного, во-вторых, тех людей, которые идут против политики правительства (их и называли врагами или интервентами). Данное неприятие выражалось весьма жестоко. Подтверждением тому служит один из плакатов советского времени: «Убей захватчика-врага». А на борьбу с иностранными интервентами поднимались так называемые народные мстители. В романе данные советизмы произносит Берлиоз, когда спрашивает у Воланда, а кто же именно его убьёт. Переводчики также воспользовались прямым соответствием, однако $19 \%$ респондентов затруднились привести ассоциации с данным советизмом.

15. Proletarian (пролетарий). Надпись: «Пролетарии всех стран, соединяйтесь!» присутствовала на гербе СССР на языках всех союзных республик и на их гербах. У данной идеологемы есть прямое соответствие, которым переводчики и воспользовались. При этом 14 \% затруднились ответить на вопрос о значении слова.

16. Intelligentsia (интеллигенция). 14 \% опрошенных затруднились написать свои ассоциации.

17. Komsomol girl (комсомолка). На первый взгляд, эта идеологема довольно известна. Однако данные опроса говорят об обратном: 14 \% затруднились его прокомментировать.

18. The tenants' association (домоуправление). Административный орган для управления жилым домом или группой жилых домов в городах играл важную роль в советские времена. Довольно распространённый советизм, который продолжает своё существование и в наши дни. Тем не менее, $14 \%$ опрошенных иностранцев испытали затруднения при понимании в силу того, что данное явление в их культуре всё-таки отсутствует.

19. Communal kitchen (общая, коммунальная кухня). Это, пожалуй, едва ли не самый известный и понятный для иностранцев советизм. Однако всё же 5 \% опрошенных затруднились написать свои ассоциации.

\section{Выводы}

Исследование показало, что в большинстве случаев иностранцы так или иначе испытывают затруднения при трактовке той или иной единицы советского периода. Происходит это потому, что они опираются на личностную систему смыслов. Однако для того, чтобы облегчить понимание вышеупомянутых единиц, необходимо опираться на языковые значения, которые можно передать с помощью калькированных вариантов, заимствования, определения, аналога, родовидовой замены.

\section{ЛИТЕРАТУРА}

1. Большая Российская энциклопедия: в 30 т. / Председатель Науч.-ред. совета Ю.С. Осипов. Отв. ред. С.Л. Кравец. Т. 19. Маниковский - Меотида. - М.: Большая Российская энциклопедия, 2012. - 767 с.

2. Стернин И.А. Практическая риторика : учеб. пособие для студ. высш. учеб. заведений // И.А. Стернин. — 5-е изд., стер. — М. : Издательский центр «Академия», 2008. - 272 c.

3. Алексеева В.Н. Ассоциативное поле советизмов 1920-1930-х гг. : на материале англоязычных изданий романа «Мастер и Маргарита» М.А. Булгакова : диссертация кандидата филологических наук : 10.02.19 // Алексеева Виктория Николаевна - Ярославль, 2016. - 170 с. [Электронный ресурс] Режим доступа [URL: https://dlib.rsl.ru/01008747231].

( Алексеева Виктория Николаевна (aka_vscorpio@mail.ru).

Журнал «Современная наука: актуальные проблемы теории и практики» 